\title{
T-cell receptor repertoire expression in workers with occupational asthma due to platinum salt
}

\author{
M. Raulf-Heimsoth*, R. Merget*, H-P. Rihs*, M. Föhring*, V. Liebers*, B. Gellert*, \\ G. Schultze-Werninghaus**, X. Baur*
}

T-cell receptor repertoire expression in workers with occupational asthma due to platinum salt. M. Raulf-Heimsoth, R. Merget, H-P. Rihs, M. Föhring, V. Liebers, B. Gellert, G. Schultze-Werninghaus, X. Baur. (C) ERS Journals Ltd 2000.

ABSTRACT: There is a high incidence of asthma, rhinitis, conjunctivitis and contact urticaria in workers of precious metal refineries. Symptoms are closely associated with sensitization to halogenated platinum compounds, as assessed by skin-prick test. The aim of the present study was to examine the molecular mechanisms involved by describing the T-cell receptor (TCR) repertoire distribution of peripheral blood mononuclear cells (PBMCs) without and after in vitro stimulation with sodium hexachloroplatinate.

PBMCs of 17 sensitized subjects with work-related asthma and a positive skin-prick test result to sodium hexachloroplatinate and of 15 nonexposed subjects were isolated and TCR expression determined by flow cytometry. Furthermore, the sodium hexachloroplatinate-mediated in vitro effects on the frequency of $\mathrm{V} \beta$-expressing $\mathrm{T}$ cells, the proliferation response and the expression of cell surface molecules like CD71, CD25, CD95 and HLA-DR were studied.

CD3-positive lymphocytes of platinum salt-sensitized workers had a significantly higher frequency of $\mathrm{V} \alpha 2 \mathrm{a}+, \mathrm{V} \beta 11+$ and $\mathrm{V} \beta 21.3+\mathrm{T}$-cells than controls $(\mathbf{p}<\mathbf{0 . 0 1}, \mathbf{p}<0.01$ and $p<0.001$ respectively). In vitro stimulation of PBMCs from platinum saltsensitized as well as control subjects with sodium hexachloroplatinate increased the percentage of CD3-positive cells bearing specific TCRs, especially V $\beta 5.3$, V $\beta 6.7$, $V \beta 8 a, V \beta 20$ and $V \beta 21.3$. This effect was time- and dose-dependent.

The present results indicate that the frequencies of $V \alpha 2 a-, V \beta 11$ and $V \beta 21.3-$ bearing blood $T$-cells and platinum salt-induced lymphocyte proliferation are strongly enhanced in subjects who suffer from asthma due to platinum salt. In addition, in vitro stimulation with sodium hexachloroplatinate modulates the frequencies of certain $T$ cell receptor-bearing T-cells.

Eur Respir J 2000; 16: 871-878.

Since 1911, when the first case reports on asthma due to platinum salts in humans were published [1], many studies have indicated a high prevalence or incidence of sensitization to Pt salt or symptoms in exposed workers in precious metal refineries [2-6] and catalyst production plants [7]. Sensitized people suffer from occupational asthma, rhinitis, conjunctivitis and/or contact urticaria. In a crosssectional study on 65 platinum workers, $23 \%$ of them had work-related respiratory symptoms [8]. Skinprick tests (SPTs) and bronchial challenge tests with Pt salts, mostly hexachloroplatinic acid or sodium hexachloroplatinate, showed immediate-type reactions in a high percentage of exposed subjects [9-13]. Although in vivo tests suggest an immunoglobulin E (IgE)-mediated mechanism, in vitro tests like radioallergosorbent tests or histamine release from basophils were reported to be far less sensitive and specific, and passive transfer tests were inconsistent [7-14]. However, total IgE levels were found to be elevated in subjects with a positive SPT to Pt salts, and it is generally believed that the in vitro test systems lack validity because an appropriate hapten/ protein conjugate is not available.
*Berufsgenossenschaftliches Forschungsinstitut für Arbeitsmedizin, Ruhr-Universität Bochum, and **Berufsgenossenschaftliche Kliniken Bergmannsheil Universitätsklinik, Medizinische Klinik und Poliklinik, Abteilung Pneumologie, Allergologie und Schlafmedizin, Bochum, Germany.

Correspondence: M. Raulf-Heimsoth, Dept of Immunology/Allergology, Berufsgenossenschaftliches Forschungsinstitut, für Arbeitsmedizin, Institut an der RuhrUniversität Bochum, Bürkle-de-la-CampPlatz 1, 44789 Bochum, Germany. Fax: 49 2343074610

Keywords: Flow cytometry, occupational allergy, platinum salt sensitivity, T-cell receptor repertoire

Received: October 141999

Accepted after revision August 42000

This work was supported by the Hauptverband der gewerblichen Berufsgenossenschaften (Central Association of the Statutory Accident Insurance Institutions in Industry and Trade), St Augustin, Germany.
Although there is convincing evidence for an immunological mechanism, the pathogenetic susceptibility and the molecular basis of the interaction between T-cells and $\mathrm{Pt}$ as well as the suggested induction of specific $\mathrm{IgE}$ synthesis are poorly understood. One means of determining the role of T-cells and their responsiveness to Pt salt is to analyse the T-cell receptor (TCR) repertoire of $\mathrm{Pt}$ salt-sensitized subjects and of Pt-activated T-cells after in vitro stimulation. The TCR $\alpha \beta$ heterodimers recognize short antigenic peptides bound to the groove of major histocompatibility complex (MHC) class II molecules on antigen-presenting cells [15-17]. The recognition of a broad variety of peptide antigens depends on the structural diversity of the TCR, which is generated during lymphocyte ontogenesis by random combinatorial rearrangement of gene elements. In contrast to the formation of covalently bound haptenized MHC-associated peptides of low molecular weight chemicals, metal ions are able to form rather stable co-ordination complexes with proteins or peptides [18-20]. This effect may induce hapten-like determinants on modified proteins or peptides. In the case of nickel hypersensitivity, strong 
overrepresentation of the TCR V $\beta 17$ element was described [19]. Although the identity of the antigenic epitopes recognized by nickel-reactive T-cells remains to be elucidated, a currently favoured model proposes that a nickel-specific TCR is activated through contact with nickel-modified self peptides embedded in the binding groove of MHC class II molecules [20]. A similar model may be possible for other metals. However, the molecular events involved in the specific Pt salt immune response are unknown.

The aim of the present study was to define the TCR repertoire in Pt salt-sensitized workers and to compare these results with nonexposed controls. In addition, the TCR repertoire in peripheral blood mononuclear cells (PBMCs) of Pt salt-sensitized and nonexposed subjects activated in vitro with sodium hexachloroplatinate was examined. Finally, the proliferation response as well as the expression of specific cell surface molecules induced by in vitro $\mathrm{Pt}$ salt stimulation was determined.

\section{Materials and methods}

\section{Subject characteristics}

Seventeen Pt salt-sensitized workers with workplacerelated asthma (mean age 42 yrs; two female, 15 male) were included in the study (table 1). Four of them worked in the catalyst department and 13 worked in the refinery. All of them showed an immediate-type SPT response (weal diameter $\geq 4 \mathrm{~mm}$ ) to $\leq 1 \mathrm{~g} \cdot \mathrm{L}^{-1}$ sodium hexachloroplatinate. Twelve $(70.5 \%)$ subjects were exclusively sensitized to sodium hexachloroplatinate and gave negative results when tested with 20 common standard allergens (monosensitized). Five of the 17 were judged atopic by means of a positive SPT to at least two com- mon allergens. Total $\mathrm{IgE}$ concentration ranged 17-657 $\mathrm{kU} \cdot \mathrm{L}^{-1}$ (median $110 \mathrm{kU} \cdot \mathrm{L}^{-1}$ ). None were on immunotherapy and/or corticosteroid therapy. The control group comprised 15 asymptomatic nonexposed subjects (mean age 37 yrs; seven female, eight male; seven current smokers, seven nonsmokers, one exsmoker). They were office workers $(n=9)$ and technicians in research laboratories $(n=6)$, who had never worked in plants with $\mathrm{Pt}$ exposure. Four of them were atopic (median total IgE $15 \mathrm{kU} \cdot \mathrm{L}^{-1}$; range $2-368 \mathrm{kU} \cdot \mathrm{L}^{-1} ; \mathrm{n}=15$ ).

Due to the extremely high specificity of skin-testing [12], control subjects were not skin-tested with sodium hexachloroplatinate.

All subjects gave informed consent for phlebotomy. The study protocol was approved by the local Ethics Committee.

\section{Platinum salt preparation}

Sodium hexachloroplatinate $\left(1 \mathrm{~g} \cdot \mathrm{L}^{-1}\right.$; provided by Degussa Huels Corporation (Frankfurt, Germany) as a $10 \mathrm{~g} \cdot \mathrm{L}^{-1}$ solution and diluted 10 -fold with saline) was used according to recent international recommendations (International Platinum Association, 1993, unpublished recommendations). For the cell stimulation experiments, further dilutions were made in the culture medium Roswell Park Memorial Institute (RPMI-1640) medium.

Determination of T-cell receptor expression and additional cell surface molecules by flow cytometry

TCR expression was determined by means of flow cytometry using a panel of 18 different monoclonal antibodies to epitopes on the variable region of the $\alpha$ and $\beta$-chains. For immunofluorescence staining, $50 \mu \mathrm{L}$

Table 1. - Platinum salt-allergic subjects

\begin{tabular}{|c|c|c|c|c|c|c|c|c|c|c|c|c|}
\hline Patient & $\begin{array}{l}\text { Age } \\
\text { yrs }\end{array}$ & $\begin{array}{l}\text { Smoking } \\
\text { status }\end{array}$ & Sex & $\begin{array}{l}\text { Total IgE } \\
\mathrm{kU} \cdot \mathrm{L}^{-1}\end{array}$ & Atopy & Symptoms $\$$ & $\begin{array}{c}\text { OET } \\
\text { months }\end{array}$ & $\begin{array}{l}\text { Time trans } \\
\text { months }\end{array}$ & $\begin{array}{c}\mathrm{SPT}^{\oplus} \\
\mathrm{mm}\end{array}$ & $\begin{array}{l}\mathrm{FEV} 1^{++} \\
\% \text { pred }\end{array}$ & $\begin{array}{c}\mathrm{PC} 50 \mathrm{MCh}^{++} \\
\mathrm{g} \cdot \mathrm{L}^{-1}\end{array}$ & $\begin{array}{c}\mathrm{PC} 50 \mathrm{Pt}^{* * *} \\
\mathrm{~g} \cdot \mathrm{L}^{-1}\end{array}$ \\
\hline 1 & 37 & Ex & M & 64 & No & $\mathrm{A}^{*}, \mathrm{R}, \mathrm{C}, \mathrm{U}$ & 66 & 60 & $15 / 16$ & $105 / 112$ & $0.9 / 1.6$ & $6 \times 10^{-3}$ \\
\hline 2 & 49 & NS & $\mathrm{F}$ & ND & No & $\mathrm{A}^{*}, \mathrm{R}, \mathrm{C}, \mathrm{U}$ & 72 & 19 & $11 / 11$ & $103 / 93$ & $0.4 / 0.5$ & $2 \times 10^{-3}$ \\
\hline 3 & 54 & $\mathrm{~s}$ & M & 123 & No & $\mathrm{A}^{*}, \mathrm{U}$ & 114 & 117 & $2 / 8$ & 89/ & $2.1 / 0.9$ & $3 \times 10^{-1}$ \\
\hline 4 & 32 & $\mathrm{~S}$ & M & 97 & No & $A^{*}, R$ & 1 & 2 & 12 & 101 & 1.2 & ND \\
\hline 5 & 39 & $\mathrm{~s}$ & M & 657 & Yes & $A^{*}, R$ & 57 & 24 & $14 / 16$ & $78 / 81$ & $0.5 / 0.3$ & $6 \times 10^{-3}$ \\
\hline 6 & 41 & NS & M & 91 & No & $A^{*}, R$ & 49 & 44 & $0 / 10$ & $123 / 123$ & $1.3 / 0.4$ & $8 \times 10^{-2}$ \\
\hline 7 & 41 & $\mathrm{~s}$ & M & 45 & No & A,R & 7 & 37 & $5 / 13$ & $124 / 119$ & $1.5 / 0.5$ & $7 \times 10^{-2}$ \\
\hline 8 & 48 & $\mathrm{~s}$ & M & 17 & No & $\mathrm{A}^{*}, \mathrm{R}, \mathrm{C}$ & 28 & 90 & $17 / 7$ & $58 / 55$ & $4.0 / \mathrm{ND}$ & $1 \times 10^{-2}$ \\
\hline 9 & 53 & Ex & M & 137 & No & $\mathrm{A}^{*}, \mathrm{R}, \mathrm{C}$ & 38 & 82 & $11 / 14$ & ND/102 & $3.1 / 0.3$ & $1 \times 10^{-3}$ \\
\hline 10 & 37 & Ex & M & 145 & No & $\mathrm{A}^{*}, \mathrm{R}, \mathrm{C}$ & 159 & 186 & 14 & 88 & 1.0 & $4 \times 10^{-3}$ \\
\hline 11 & 36 & NS & M & 31 & No & $\mathrm{A}^{*}, \mathrm{R}^{*}, \mathrm{C}^{*}$ & 64 & 36 & 5 & 80 & ND & ND \\
\hline 12 & 45 & $\mathrm{~s}$ & M & 371 & Yes & $A^{*}$ & 43 & 8 & 5 & 68 & 1.0 & $\mathrm{ND}^{\# \#}$ \\
\hline 13 & 33 & Ex & M & 239 & No & $\mathrm{A}^{*}, \mathrm{R}^{*}, \mathrm{C}^{*}$ & 41 & 1 & 8 & 76 & 0.7 & $2 \times 10^{-2}$ \\
\hline 14 & 37 & $\mathrm{~s}$ & M & 206 & Yes & $\mathrm{R}, \mathrm{C}$ & 40 & 6 & 15 & 85 & 0.9 & ND \\
\hline 15 & 42 & s (pipe) & $\mathrm{M}$ & 53 & No & $\mathrm{A}^{*}, \mathrm{R}, \mathrm{C}, \mathrm{U}$ & 67 & 74 & $12 / 13$ & $110 / 105$ & $1.0 / 0.3$ & $1 \times 100$ \\
\hline 16 & 39 & $\mathrm{~S}$ & $\mathrm{M}$ & 243 & Yes & $\mathrm{A}^{*}, \mathrm{R}, \mathrm{C}, \mathrm{U}$ & 115 & 30 & $5 / 0$ & $80 / 79$ & $0.2 / 0.3$ & $5 \times 10^{-2}$ \\
\hline 17 & 55 & Ex & M & 165 & Yes & $\mathrm{A}^{*}, \mathrm{R}, \mathrm{C}, \mathrm{U}$ & 240 & 140 & $14 / 15$ & $55 / 45$ & $2.6 / 0.4$ & ND \\
\hline
\end{tabular}

${ }^{+}$: patients 4, 8, 12 and 14 worked as catalyst operators; all the rest were refinery operators; ${ }^{*}$ : positive skin-prick test to at least two common environmental allergens; ${ }^{\S}$ : work-related symptoms before transferral; *: current symptoms; ${ }^{\star}$ : prior to examination; ${ }^{\uparrow}$ : weal diameter with $1 \mathrm{~g} \cdot \mathrm{L}^{-1}$ sodium hexachloroplatinate at diagnosis/present examination; ${ }^{++}$: at diagnosis/present examination; **: at diagnosis (Pt salts); ${ }^{\# \#}$ : positive nasal challenge. IgE: immunoglobulin E; OET: occupational exposure time (in metal plant building); trans: transferred; SPT: skin-prick test; FEV1: forced expiratory volume in one second; \% pred: percentage of the predicted value; PC50: provocative concentration of agent causing a 50\% decrease in specific airway conductance; MCh: methacholine; Ex: exsmoker; NS: nonsmoker; s: smoker; M: male; F: female; ND: not determined; A: asthma; R: rhinitis; C: conjunctivitis; U: contact urticaria. 
PBMCs $\left(1 \times 10^{5}\right)$ were incubated in the presence of saturated concentrations of fluorescein isothiocyanate (FITC)or phycoerythrin (PE)-conjugated monoclonal antibodies (mAbs) for $30 \mathrm{~min}$ in the dark at $4^{\circ} \mathrm{C}$. Double staining was performed with PE-labelled anti-CD3 (Becton Dickinson, Heidelberg, Germany) and FITC-labelled anti-V $\alpha 2 \mathrm{a}$ or the anti-V $\beta \mathrm{x}$. mAbs directed against TCR variants were purchased from: DPC Biermann, Bad Nauheim, Germany (Vo2a (clone F1)); Coulter-Immunotech, Hamburg, Ger-

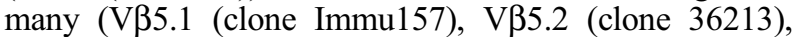
$\mathrm{V} \beta 8$ (clone 56C5), V $\beta 11$ (clone C21), V $\beta 12$ (clone S511),

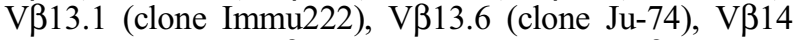

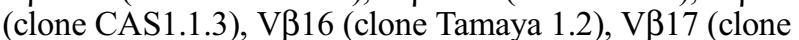

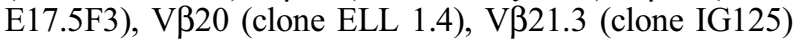
and V $\beta 22$ (clone Immu546)); and Biozol-Endogen, Eching, Germany (V $\beta 5 . b$ (clone W112; recognizes V $\beta 5.3$ ),

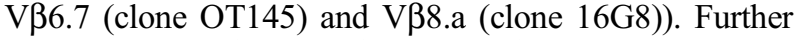
cell surface markers used for cell characterization were CD71 (Dianova, Hamburg, Germany) and CD25, CD95 and HLA-DR (Becton Dickinson), each in combination with CD3. Two-colour cytofluorometric analysis was performed using fluorescence-activated cell sorting FACSStar Plus; (Becton Dickinson) with an argon laser (488 nm, air-cooled) (as described in detail elsewhere [21]). Acquisition and analysis were carried out using the Lysis 1.0 programme (Becton Dickinson, Heidelberg, Germany). For each test, $\geq 10,000$ cells were acquired. The lymphocyte population was identified using forward and 90degree light scatter patterns.

Specific in vitro stimulation with sodium hexachloroplatinate to determine T-cell receptor expression

PBMCs were separated by means of Ficoll/Hypaque gradient centrifugation and adjusted to $1 \times 10^{6}$ cells $\cdot \mathrm{mL}^{-1}$ in RPMI-1640 (Gibco, Eggenstein, Germany) conditioned medium supplemented with glutamine $(2 \mathrm{mM})$, penicillin $(100 \mathrm{u}) /$ streptomycin $(100 \mu \mathrm{g})$ and $10 \%$ heat-inactivated pooled human AB sera (Bavarian Red Cross, Munich, Germany). Isolated PBMCs were stored at $-196^{\circ} \mathrm{C}$ until use. For determination of the baseline profile of TCR expression, thawed PBMCs were washed and resuspended in RPMI and, without further stimulation, stained with the specific $\mathrm{mABs}$ and analysed by flow cytometry. In addition to the TCR baseline profile, PBMCs were incubated in the presence of RPMI, hexachloroplatinate $\left(5,25,50\right.$ and $\left.100 \mu \mathrm{g} \cdot \mathrm{mL}^{-1} ; 1.2 \times 10^{-5}-2.4 \times 10^{-4} \mathrm{M}\right)$ or phytohaemagglutinin (PHA; Sigma, Deisenhofen, Germany; $7.5 \mu \mathrm{g} \cdot \mathrm{mL}^{-1}$ ) in 24-well, flat-bottom microtitre plates (Falcon, BectonDickinson, Heidelberg, Germany) in a 2-mL volume at $37^{\circ} \mathrm{C}$ and under $5 \% \mathrm{CO}_{2}$ for $2,3,5$ or 7 days. After stimulation, the cells were analysed by FACS as described above for the analysis of unstimulated cells with the exception that forward and 90-degree light scatter patterns were used to gate on lymphocyte blasts rather than the smaller lymphocyte population $[22,23]$.

Determination of specific $T$-cell receptor $V \beta$-gene segment families by molecular biological techniques

Total ribonucleic acid (RNA) was extracted from $5 \times 10^{6}$ PBMCs using an Rneasy ${ }^{\mathrm{TM}}$ Mini Kit (Qiagen, Hilden, Germany) according to the standard protocol of the supplier. Total RNA $(1-5 \mu \mathrm{g})$ was converted to complemetnary deoxyribonucleic acid (DNA) (cDNA) by standard methods using reverse transcriptase Superscript 11 (Life Technologies, Karlsruhe, Germany) and $0.5 \mu \mathrm{g}$ Oligo-deoxythymidine primer amplified by the polymerase chain reaction (PCR) technique. V $\beta$-specific products were generated using primers based exactly on published sequences previously tested for specificity and sensitivity [24]. TCR primers specific to V $\beta 1-20$ were used in conjunction with a common $C \beta$ region primer (5'-TTCTGATGGCTCAAACAC-3'). Negative controls without template cDNA in the reaction mixture were included in each batch. Successful amplification of the actin gene using the primer pair actin-5 (5'-GTGGGCCGCTCTAGGCACCA-3') actin-3 (5'CGGTTGGCCTTAGGGTTCAGGG-GG3') served as positive control. PCR products were separated on $1.5 \%$ agarose gels and analysed after ethidium bromide staining. If necessary, Southern blot experiments were performed as described [24].

\section{Platinum salt-specific lymphocyte proliferation}

The method used for PBMC proliferation has recently been described in detail [25]. Briefly, six replicate cultures of thawed PBMCs were set up in 96-well roundbottom trays in a $200 \mu \mathrm{L}$ volume, generally at a concentration of $5 \times 10^{5}$ cells $\cdot \mathrm{mL}^{-1}$. Hexachloroplatinate was added to the wells in different concentrations (500$\left.0.1 \mu \mathrm{g} \cdot \mathrm{mL}^{-1} ; 1.2 \times 10^{-3}-2.4 \times 10^{-7} \mathrm{M}\right)$ at the beginning of culture, which was performed in a humidified atmosphere containing $5 \% \mathrm{CO}_{2}$ for 5 days at $37^{\circ} \mathrm{C}$. Negative controls of cells alone in the presence of medium (RPMI-1640) and positive controls of cells incubated with PHA (7.5 $\mu \mathrm{g} \cdot \mathrm{mL}^{-1}$ ) were included in each assay. For the final $12 \mathrm{~h}$, $37 \mathrm{kBq}$ of ${ }^{3} \mathrm{H}$-labelled thymidine-methyl were added to each well, and the incorporated radioactivity was assessed by liquid scintillation spectrometry.

Because background proliferation (proliferation in the presence of RPMI alone) varied significantly among individuals, responses to the Pt salt were expressed as a stimulation index (SI). The SI is the ratio of the mean radioactivity (counts per minute) obtained in the six similar cultures with allergen and that obtained in the allergen-free culture (RPMI control). The cut-off limits determining positive and negative responses were tentatively set at an SI of 2.5 for specific responses [25]. The SD of the six determinations was $10-25 \%$.

\section{Histocompatibility leukocyte antigen class II typing}

Histocompatibility leukocyte antigen class II-typing was performed in 14 of the $17 \mathrm{Pt}$ salt-sensitized patients as well as in 10 control subjects (table 2). Genomic DNA was extracted from frozen white blood cells using a DNA Easy-Prep kit (Lifecodes, Herenthals, Belgium) as recommended by the supplier. DNA typing was performed with Histo Type DNA-DQ and -DR kits (Biologische Analysesysteme $\mathrm{GmbH}$, Lich, Germany), based on the PCR amplification of 24 sequence-specific primer pairs for DRB1 and 16 specific primer pairs for DQB1, according to the supplier's protocol. These methods enable identification of the broad DRB1 and DQB1 alleles equivalent to the serological specification, and, in some cases, further subdivision. 
Table 2. - Histocompatibility leukocyte antigen class II typing of platinum salt-sensitized subjects and controls

\begin{tabular}{|c|c|c|c|c|}
\hline Subject No & DRB1* & DRB1* & DQB1* & DQB* \\
\hline \multicolumn{5}{|l|}{ Patients } \\
\hline 1 & 01 & 0701 & 0501 & $0201-2$ \\
\hline 2 & \multicolumn{2}{|c|}{ ND } & \multicolumn{2}{|c|}{ ND } \\
\hline 3 & 06 & & 0603-9 & $0502-4$ \\
\hline 4 & 01 & $1401 / 7$ & 0501 & $0502-4$ \\
\hline 5 & 15 & 12 & 0602 & 0301 \\
\hline 6 & 04 & & 0302,7 & \\
\hline 7 & 12 & 0701 & 0301 & $0201-2$ \\
\hline 8 & 15 & & 0602 & \\
\hline 9 & 15 & 11 & 0602 & 0301 \\
\hline 10 & 04 & 03 & 0302,7 & $0201-2$ \\
\hline 11 & 02 & 0701 & $0502-4$ & 0303 \\
\hline 12 & 06 & 0701 & $0201-2$ & 0303 \\
\hline 13 & 03 & 04 & $0201-2$ & 0302,7 \\
\hline 14 & \multicolumn{2}{|c|}{ ND } & \multicolumn{2}{|c|}{ ND } \\
\hline 15 & 03 & 04 & $0201-2$ & 0302,7 \\
\hline 16 & 0701 & & $0201-2$ & \\
\hline 17 & \multirow{2}{*}{\multicolumn{2}{|c|}{ ND }} & \multirow{2}{*}{\multicolumn{2}{|c|}{ ND }} \\
\hline Controls & & & & \\
\hline 1 & 03 & 12 & $0201-2$ & 0301 \\
\hline 2 & 0701 & 08 & 0303 & $0401-2$ \\
\hline 3 & 04 & & 0302.7 & \\
\hline 7 & 04 & & 0302.7 & \\
\hline 8 & 0701 & & 0303 & \\
\hline 9 & 03 & 06 & $0201-2$ & $0603-9$ \\
\hline 10 & 04 & 15 & 0302.7 & 0602 \\
\hline 11 & 15 & & 0602 & \\
\hline 12 & 01 & 15 & 0501 & 0602 \\
\hline 13 & 03 & & $0201-2$ & \\
\hline
\end{tabular}

ND: not determined.

\section{Statistics}

The results of TCR expression are presented as individual values with medians or mean \pm SD. Wherever relevant, statistical analysis was performed using the two-sided Wilcoxon-Mann-Whitney test. Due to the large number of comparisons, a $p$-value of $\leq 0.01$ was used to determine significance. Quantitative proliferation data were expressed as the mean of at least six determinations. Fisher's exact text (two-tailed) was used for comparison of proliferation data obtained in the $\mathrm{Pt}$ and in the control group and carried out using the StatXact program (Cytel Software, Cambridge, MA, USA).

\section{Results}

T-cell receptor expression without further in vitro stimulation (baseline profile)

Isolated PBMCs were obtained from $17 \mathrm{Pt}$ saltsensitized workers and 15 controls, and the percentage of CD3-positive T-cells expressing particular $\mathrm{V}$ regions was determined by immunofluorescence staining and cytofluorographic analysis. The frequency of CD3-positive lymphocytes in Pt salt-sensitized workers was significantly higher $(\mathrm{p} \leq 0.01)$ for $\mathrm{V} \alpha 2 \mathrm{a}$ - (median 5.54 versus $3.49 \%$; $\mathrm{p}<0.01)$, V $\beta 11$ (0.65 versus $0.31 \% ; \mathrm{p}<0.01)$ and $\mathrm{V} \beta 21.3-$ positive T-cells $(1.79$ versus $0.9 \%$; $\mathrm{p}<0.001)$ than in controls (fig. 1a). A tendency towards enhanced expression of Vß5.2 (0.91 versus $0.53 \% ; \mathrm{p}<0.05), \mathrm{V} \beta 13.1(0.99$ versus $0.29 \% ; \mathrm{p}<0.05), \mathrm{V} \beta 14$ (0.82 versus $0.24 \%$; $\mathrm{p}<0.05)$ and $\mathrm{V} \beta 17(3.51$ versus $1.57 \% ; \mathrm{p}<0.05)$ was also observed within the CD3-positive lymphocytes of $\mathrm{Pt}$ salt-sensitized workers. Representatively, for the individual distribution, the percentages of the V $\beta 21.3$-positive T-cell subpopulations in controls and $\mathrm{Pt}$ salt-sensitized workers are shown in figure $1 \mathrm{~b}$. In a subgroup of $12 \mathrm{Pt}$ salt-sensitized workers, who were sensitized to Pt alone, the percentage of Vß21.3-bearing cells was also significantly higher when compared with the control group (median 1.77 versus $0.9 \%$; $<<0.001$ ).

Analysis of 20 TCR V $\beta$ gene segment families was also performed by reverse transcriptase PCR followed by V $\beta$ specific amplification of cDNA. With the exception of $\mathrm{V} \beta 16$ and $\mathrm{V} \beta 17$ transcripts, all V $\beta$ transcripts were detectable in $90-100 \%$ of individuals investigated. No
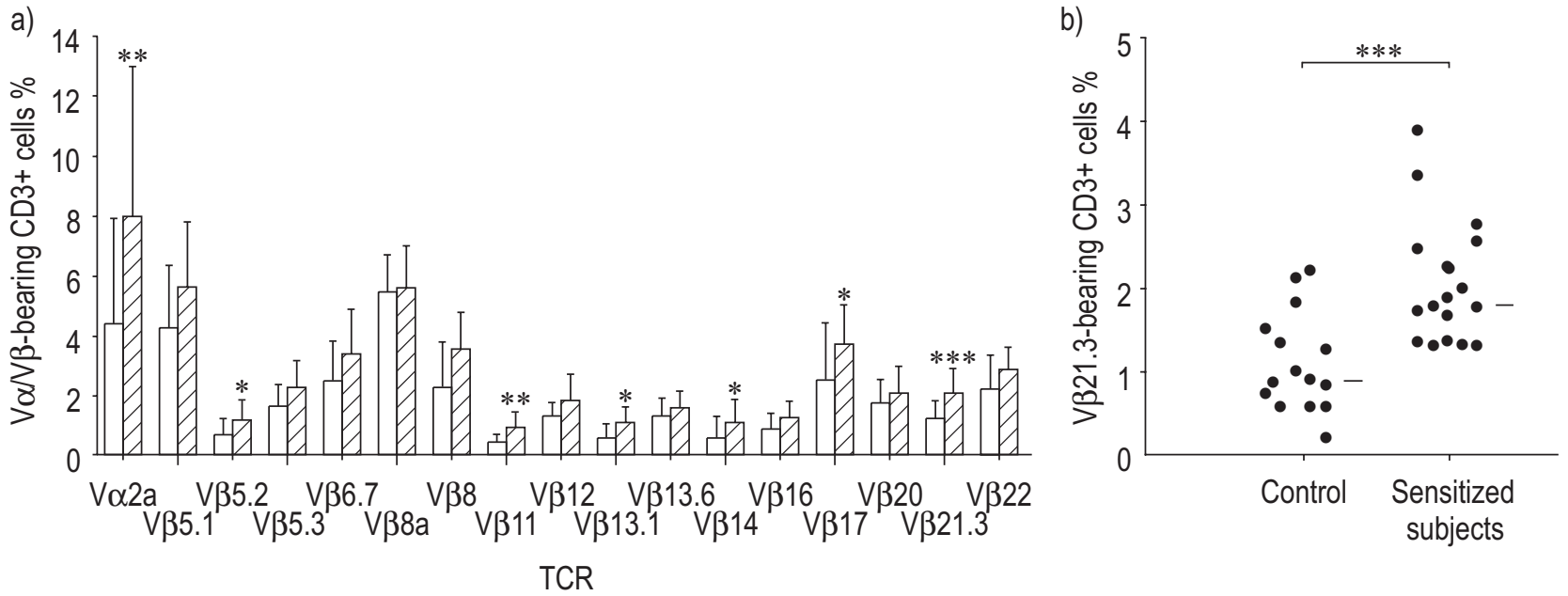

Fig. 1. - a) T-cell receptor (TCR) repertoires of platinum salt-sensitized subjects ( $\mathbb{Z} ; n=17)$ and controls $(\square ; n=15)$. The expression of the different TCR $\mathrm{V} \beta \mathrm{s}$ in the peripheral blood mononuclear cells (PBMCs) was assessed by flow cytometry using specific monoclonal antibodies. The frequency of the different TCRs was determined in PBMCs without further in vitro stimulation (baseline profile). Data are presented as mean \pm SD. *: $\mathrm{p}<0.05$; **: $\mathrm{p}<0.01$, $* * *: \mathrm{p}<0.001$ versus control. b) Frequency of V $\beta 21.3$ in Pt salt-sensitized subjects $(\mathrm{n}=17)$ and controls $(\mathrm{n}=15)$. Data are presented as individual values; the horizontal bar represents the median. ${ }^{* * *}: \mathrm{p}<0.001$. 


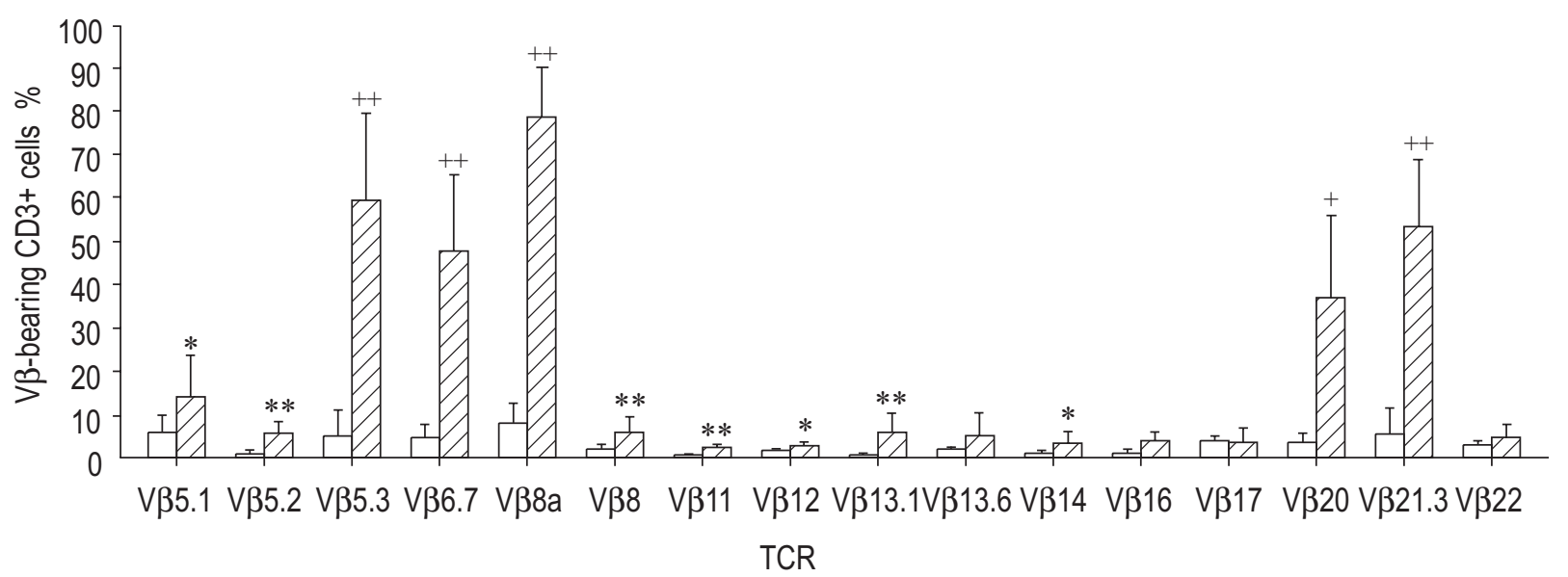

Fig. 2. - T-cell receptor (TCR) profile of CD3-positive cells incubated in vitro with sodium hexachloroplatinate (ש) or Roswell Park Memorial Institute (RPMI) medium ( $\square$; medium control). The peripheral blood mononuclear cells (PBMCs) of six individuals (randomly selected) were incubated with sodium hexachloroplatinate $\left(50 \mu \mathrm{g} \cdot \mathrm{mL}^{-1}\right)$ or RPMI for 5 days. Expression of the different V $\beta$ s on T-cells was assessed by flow cytometry using monoclonal antibodies recognizing specific TCRs. Data are presented as mean \pm SD. ${ }^{*}: \mathrm{p}<0.05 ;{ }^{* *}: \mathrm{p}<0.01 ;{ }^{+}: \mathrm{p}<0.002 ;{ }^{++}: \mathrm{p}<0.0002$ versus control.

significant differences between Pt saltsensitized workers and controls were detectable (data not shown).

In addition, data regarding the HLA types of Pt saltsensitized subjects $(\mathrm{n}=14)$ and 10 controls are available (table 2). No elevated phenotypic frequency of the DRB or DQB1 alleles were detectable in the Pt salt-sensitized subjects and no significant differences were observed between Pt salt-sensitized workers and controls.

T-cell receptor profile of CD3-positive cells stimulated in vitro with sodium hexachloroplatinate

Figure 2 shows the V $\beta$ element profile of gated TCR CD3-positive cells as assessed by FACS staining. The number of $\mathrm{V} \beta 5.3, \mathrm{~V} \beta 6.7, \mathrm{~V} \beta 8 \mathrm{a} / \mathrm{V} \beta 8, \mathrm{~V} \beta 13.1, \mathrm{~V} \beta 20$ and $\mathrm{V} \beta 21.3$-positive CD3 cells was strongly enhanced in Pt salt cultures (stimulation for 5 days in the presence of $50 \mu \mathrm{g} \cdot \mathrm{mL}^{-1}\left(1.2 \times 10^{-4} \mathrm{M}\right)$ sodium hexachloroplatinate) in comparison with cultures without further stimulation

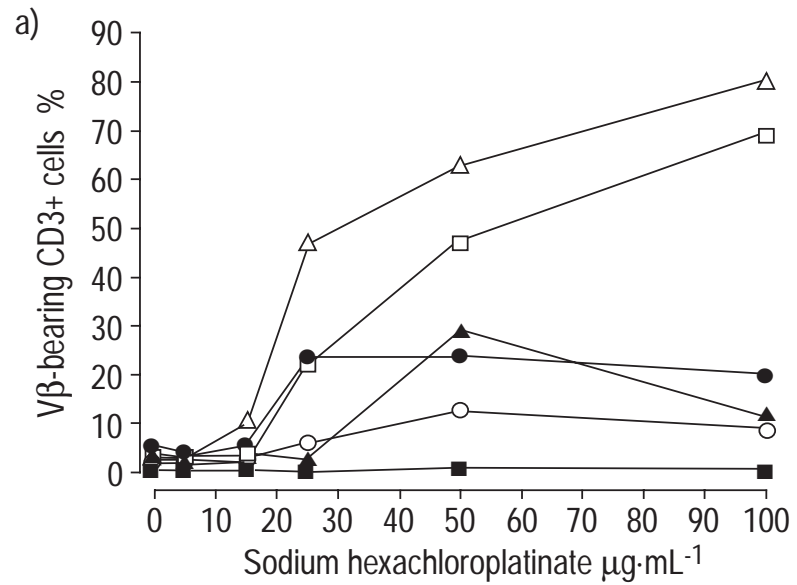

(medium control). The increase in T-cell subpopulations bearing specific $\mathrm{V} \beta$ elements was observed in the PBMCs of Pt salt-sensitized subjects as well as in controls. Incubation with five different Pt salt concentrations $\left(5,15,25,50\right.$ and $\left.100 \mu \mathrm{g} \cdot \mathrm{mL}^{-1}\right)$ yielded a dose-response curve for the expansion of the above-mentioned specific TCR-bearing CD3-positive cells (fig. 3a). A hexachloroplatinate concentration of $15 \mu \mathrm{g} \cdot \mathrm{mL}^{-1}$ induced an increase in V $\beta 8$ a-bearing $\mathrm{T}$-cells. At higher concentrations, the

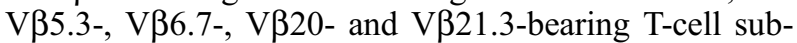
populations also showed increased frequencies. Pronounced effects were detected for $\mathrm{V} \beta 8 \mathrm{a}$ and $\mathrm{V} \beta 5.3$ in the concentration range $50-100 \mu \mathrm{g} \cdot \mathrm{mL}^{-1}$. In contrast, other $\mathrm{V} \beta$ on TCR-bearing cells, such as V $\beta 11, \mathrm{~V} \beta 14, \mathrm{~V} \beta 17$ and $\mathrm{V} \beta 22$, were not significantly affected by incubation with different Pt salt concentrations. Incubation of the PBMCs with $50 \mu \mathrm{g} \cdot \mathrm{mL}^{-1}$ sodium hexachloroplatinate for different times (0 (baseline profile), 2, 3, 5 and 7 days) demonstrated a time-dependent increase in the frequency of V $\beta 8 \mathrm{a}-, \mathrm{V} \beta 5.3-, \mathrm{V} \beta 21.3-, \mathrm{V} \beta 6.7-$ and V$\beta 20$-positive b)

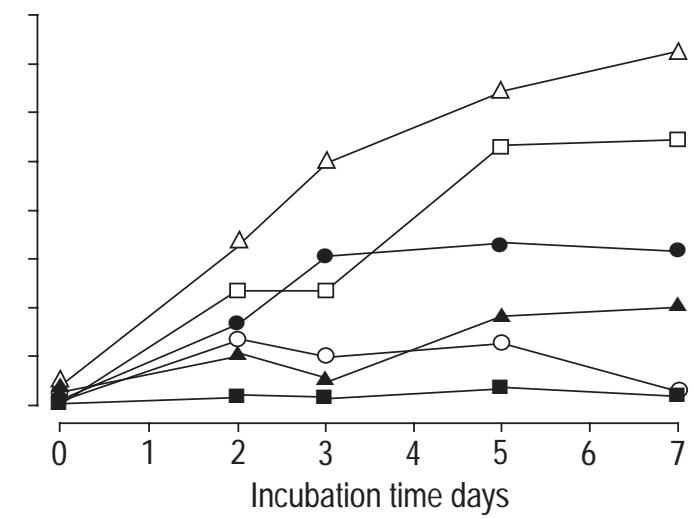

Fig. 3. - a) Dose/response curve for V $\beta$ expression on T-cell receptor (TCR)-bearing T-cells; peripheral blood mononuclear cells (PBMCs) were incubated in the presence of $0-100 \mu \mathrm{g} \cdot \mathrm{mL}^{-1}$ sodium hexachloroplatinate $\left(0 \mu \mathrm{g} \cdot \mathrm{mL}^{-1}\right.$ : Roswell Park Memorial Institute medium alone) for $5 \mathrm{days}$. b) Time course of $\mathrm{V} \beta$ expression on TCR-bearing T-cells; PBMCs were incubated in the presence of $50 \mu \mathrm{g} \cdot \mathrm{mL}^{-1}$ sodium hexachloroplatinate for different times $(2,3,5$ or 7 days ( 0 days: baseline profile)). TCR repertoires were determined by flow cytometry using specific monoclonal antibodies, $(\square:$ V $\beta 5.3 ; \boldsymbol{\Lambda}$ : $\mathrm{V} \beta 6.7 ; \triangle: \mathrm{V} \beta 8 \mathrm{a} ; \bigcirc: \mathrm{V} \beta 20 ; \bigcirc: \mathrm{V} \beta 21.3 ; \square: \mathrm{V} \beta 14)$. The frequencies of $\mathrm{V} \beta 5.1, \mathrm{~V} \beta 5.2, \mathrm{~V} \beta 11, \mathrm{~V} \beta 12, \mathrm{~V} \beta 13.1, \mathrm{~V} \beta 13.6, \mathrm{~V} \beta 16, \mathrm{~V} \beta 17$ and $\mathrm{V} \beta 22 \mathrm{were}$ not significantly influenced by different platinum salt doses. In each case, the curves show the results of one representative experiment out of three. 


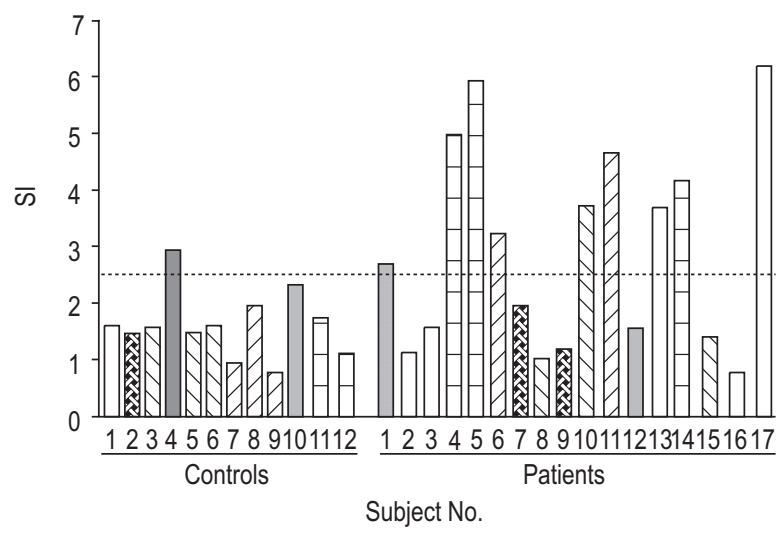

Fig. 4. - Peripheral blood mononuclear cell proliferation response to sodium hexachloroplatinate $\left(\square: 0.1 \mu \mathrm{g} \cdot \mathrm{mL}^{-1} ; \mathbb{Z}: 0.5 \mu \mathrm{g} \cdot \mathrm{mL}^{-1} ; \mathbb{\mathbb { Q }}: 1\right.$ $\mu \mathrm{g} \cdot \mathrm{mL}^{-1}$; $: 5 \mu \mathrm{g} \cdot \mathrm{mL}^{-1}$; : $10 \mu \mathrm{g} \cdot \mathrm{mL}^{-1}$; : $50 \mu \mathrm{g} \cdot \mathrm{mL}^{-1}$; 囬: 100 $\mu \mathrm{g} \cdot \mathrm{mL}^{-1}$ ) presented as stimulation indexes (SIs) for each subject. Data are means $(n \geq 6)$. A positive antigen-specific proliferation response was detected in nine of $17(53 \%)$ platinum salt-sensitized subjects and in only one of the $12(8.3 \%)$ controls $(\mathrm{p}<0.02)$. - - - : cut-off line for positive response.

T-cells (fig. $3 \mathrm{~b}$ ), with a pronounced effect on V $\beta 8 \mathrm{a}$ - and V $\beta 5.3$ frequency. Other V $\beta$ on TCR-bearing T-cell subpopulations, like those mentioned above, were not affected by the duration of the incubation time. Stimulation of the PBMCs of four subjects with PHA $\left(7.5 \mu \mathrm{g} \cdot \mathrm{mL}^{-1}\right)$ for different times showed no significant influence on the frequencies of $\mathrm{V} \beta$-bearing T-cells (data not shown).

\section{Lymphocyte proliferation response to sodium hexa- chloroplatinate}

PBMCs of the $17 \mathrm{Pt}$ salt-sensitized subjects and 12 controls were stimulated with different concentrations of sodium hexachloroplatinate (fig. 4). Nine of the 17 (53\%) patients and only one of the $12(8.3 \%)$ controls showed pronounced proliferation responses $(\mathrm{SI} \geq 2.5) \quad(\mathrm{p}=0.019$, Fisher's exact test). The Pt salt-induced lymphocyte proliferation occurred over a wide concentration range $\left(0.1-100 \mu \mathrm{g} \cdot \mathrm{mL}^{-1}\right)$, and the optimal dose varied between

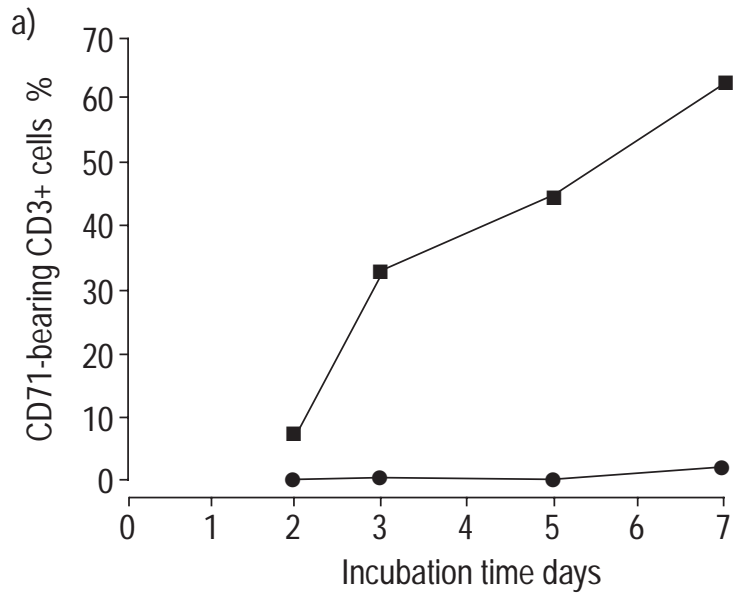

individuals. The mean proliferation response of PBMCs (stimulated with different concentrations of the Pt salt) obtained from the Pt salt-sensitized subjects (SI range $0.98-6.14$; median $2.68 ; \mathrm{n}=136$ ) was greater than that of the 12 controls (SI range 0.2-2.9; median 1.28; $\mathrm{n}=72$ ).

Effects of sodium hexachloroplatinate stimulation on the expression of various cell surface markers

In addition to the frequencies of different TCR V $\beta$ bearing T-cells, the expression of CD71, CD95, CD25 and HLA-DR on T-cells obtained after incubation with different concentrations of sodium hexachloroplatinate for various incubation times were determined. Figure 5a shows that the frequency of CD71 (transferrin receptor, which is upregulated on proliferating cells) bearing Tcells was significantly increased by prolonged incubation with Pt salt (up to $70 \%$ on day 7 ) and was also enhanced by increasing concentrations of $\mathrm{Pt}$ salt when incubated for 5 days (fig. 5b). In contrast to the frequency of CD71bearing T-cells obtained after incubation of PBMCs from seven donors with culture medium alone for 5 days (median $1.2 \%$; mean \pm SD $2.47 \pm 2.96 \%$ ), incubation with Pt salt induced, in PBMCs from the same donors, a significantly higher frequency of CD71-bearing T-cells (median 41.1\%; mean \pm SD $41.67 \pm 16.78 \%$; $p<0.0002$ ). An increase in the frequency of HLA-DR-positive T-cells was likewise observed in the presence of $50 \mu \mathrm{g} \cdot \mathrm{mL}^{-1}$ sodium hexachloroplatinate (RPMI: median 3.65\%, mean \pm SD $3.73 \pm 0.91 \%$; sodium hexachloroplatinate: median $12.23 \%$, mean \pm SD $13.64 \pm 6.06 \%, \mathrm{p}<0.01)$. No significant influence of $\mathrm{Pt}$ salt incubation could be observed on the frequency of either CD25-positive or CD95positive T-cells.

\section{Discussion}

The present investigation into TCR V $\beta$ and V $\alpha$ repertoires in a population of $\mathrm{Pt}$ salt-sensitized workers revealed restricted usage of $\mathrm{V} \beta 21.3, \mathrm{~V} \beta 11$ and $\mathrm{V} \alpha 2 \mathrm{a}$ in affected individuals since there was an increase in the

b)

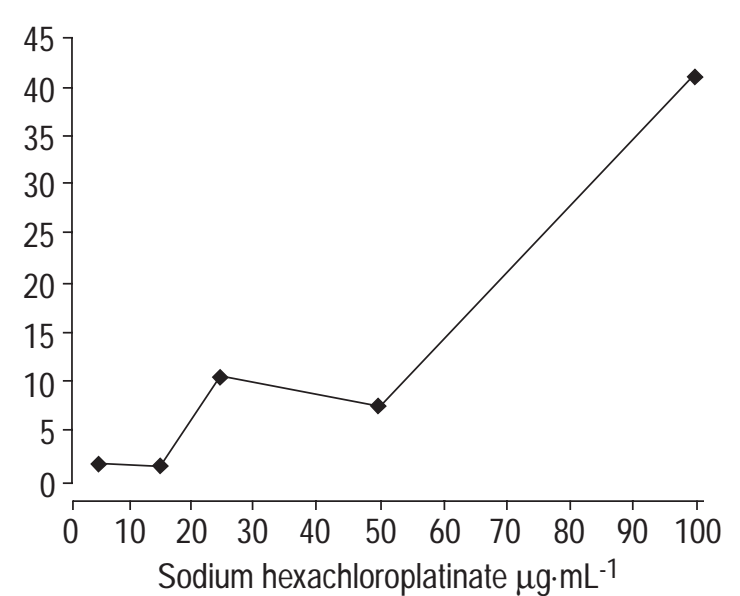

Fig. 5. - a) Time course; and b) dose/response curve showing the effects of incubation with sodium hexachloroplatinate ( $\mathbf{0}$ : medium alone; $\mathbf{\square}$ : 0 $\mu \mathrm{g} \cdot \mathrm{mL}^{-1}$ ) on the percentage of CD71-positive T-cells. CD71 was upregulated on proliferating T-cells. Both curves show representative results from two of four different experiments. 
T-cell subpopulations bearing these specific T-cell receptors. The latter represent the antigen recognition unit of T-cells. The TCR repertoire is shaped during early maturation of the immune system and is assumed to be stable over time. However, the effects of occupational allergen exposure on the relative distribution of different TCR V $\beta$ elements have not been studied extensively. BERNSTEIN et al. [26] described a significant decrease in V $\beta 1$ and V $\beta 5$ gene segment expression in patients with diisocyanateinduced occupational asthma at baseline, but a significant increase after in vitro antigenic stimulation. A subgroup of patients suffering from chronic beryllium disease showed expansion of V $\beta 3$-expressing T-cells [27]. A recent publication regarding the TCR repertoire in individuals sensitized to birch pollen and cat allergens revealed restricted usage of $\mathrm{V} \beta 16.1 / \mathrm{V} \beta 20.1$ and $\mathrm{V} \beta 17.1$ in affected individuals [28]. The observed relation in the present study as well as in previously published studies between $\mathrm{V} \beta$ expression, allergen exposure and sensitization, respectively, emphasizes the importance of allergen exposure in transiently shaping the T-cell repertoire.

T-cell responses to numerous different antigens or the use of different presenting molecules in blood could also contribute to a heterogeneous blood TCR repertoire in patients, perhaps reflecting the ability of Pt salts to complex with multiple different proteins or peptides. The present results suggest that selective expansion or accumulation of certain CD3-positive T-cell subsets occurs in the blood of patients with Pt salt-sensitization and not in the control group of nonexposed subjects. It seems reasonable to speculate that this is related to in vivo stimulation of the antigen involving Pt. The nature of such an antigen is unknown. The mechanism by which Pt salt activates T-cells is not clear. In order to exclude the possibility that the modified frequency of specific TCRbearing T-cells was caused by a mitogenic effect of Pt salt, the stimulation results were compared with those of a conventional mitogen such as PHA. However, in contrast to Pt salt incubation, PHA did not induce an increase in the frequency of specific TCR-bearing T-cells. Another possible mechanism by which Pt salt might induce reactivity is the binding of $\mathrm{Pt}$ salt to different self peptides among the MHC class II molecules. The modified MHC peptide complex would then be regarded as foreign by CD4positive cells. Since Pt ions might bind to different peptides in the MHC, an oligo- or multiclonal T-cell response would be induced. This reaction mechanism was suggested for the reactive nickel ion in sensitized individuals, in whom nickel was shown to interact with MHC-presented peptides [19]. This mechanism has also been discussed for mercury-induced cell activation [29].

It has been hypothesized that $\mathrm{Pt}$ salt may bind to different self peptides which are recognized as foreign when presented by class II MHC molecules. It is also possible that Pt salt acts as a superantigen in the human PBMC system. Superantigens are a group of molecules that differ from peptide antigens in the way in which they activate T-cells. A characteristic superantigen binds to a constant region of the HLA class II molecule and to a selected set of T-cells bearing a certain TCR V $\beta$ chain. The relative number of $\mathrm{V} \beta$ genes is limited; thus superantigens can interact with a large proportion of T-cells. The CD4-positive T-cell is the main target cell, but it was shown that CD8-positive T-cells could also interact with certain superantigen/MHC class II antigen complexes. Due to these interactions, superantigens activate $5-25 \%$ of Tcells $[28,29]$. The present findings, showing selective expansion of T-cells that express different V $\beta \mathrm{s}$ in different patients, appear to be most consistent with conventional antigen (peptides) recognition. The variability of TCR V usage in different patients with Pt saltsensitization makes superantigen features of $\mathrm{Pt}$ salt stimulation unlikely. However, without sequencing the junctional region of the expanded specific TCR-bearing T-cells and defining the presence of clonal TCR expression, the possibility that Pt salt combines with selfpeptides and class II MHC molecules in some way as a superantigen to stimulate T-cells cannot be excluded. The present authors' hypothesis that Pt salt has characteristics of a superantigen was supported by LoFTENIUS et al. [30] in their study of $\mathrm{HgCl}_{2}$. Similar to mercury chlorideinduced lymphocyte activation, two distinct mechanisms of $\mathrm{Pt}$ salt/cell interaction may be possible. One is the superantigen-like mechanism affecting T-cells from most humans and the other is possible in sensitized individuals with a specific immune reaction directed against Ptmodified self peptides presented by the MHC class II molecule. Metal ions have been shown to modify the structure of different MHC/peptide complexes [31]. Thus the specific immune response to Pt salt could be hidden by the superantigen-like response in vitro, and might explain why no differences in the TCR profile and expression of other cell surface markers can be observed between sensitized and healthy nonexposed individuals.

Pt salt also induced in vitro expansion of specific TCRbearing T-cells. In the case of $\mathrm{V} \beta 21.3$, the in vivo accumulation of TCR V 321.3 -expressing T-cells correlated with the in vitro expansion of the same T-cell subset. By in vitro stimulation, levels of V $\beta 5.3, \mathrm{~V} \beta 6.7, \mathrm{~V} \beta 8 \mathrm{a}, \mathrm{V} \beta 20$ and $\mathrm{V} \beta 21.3$, in particular, were strongly enhanced in $\mathrm{Pt}$ salt T-cell cultures in a dose- and time-dependent manner. The lymphocyte activation capacity of the Pt salt in vitro demonstrated by the lymphocyte proliferation response and the expression of different T-cell markers such as CD71 and HLA-DR seems to be independent of the MHC haplotype since the expansion of specific TCRbearing T-cell subpopulations is induced by PBMCs from almost all individuals and not limited to the Ptsensitized subjects. In addition, all PBMC donors for the in vitro stimulation experiments had different MHC types (table 2).

In conclusion, the present results indicate that platinum salt sensitization is associated with an expansion of specific T-cell receptor-bearing blood T-cell subpopulations (V $\beta 21.3, \mathrm{~V} \beta 11$ and $\mathrm{V} \alpha 2 \mathrm{a})$. Furthermore, in vitro stimulation of peripheral blood mononuclear cells with sodium hexachloroplatinate leads to an increase in the frequencies of T-cells bearing V $\beta 5.3, \mathrm{~V} \beta 6.7, \mathrm{~V} \beta 8 \mathrm{a}, \mathrm{V} \beta 20$ and $\mathrm{V} \beta 21.3$, and to additional activation measured as proliferation and increased CD71- and histocompatibility leukocyte antigen-DR expression. Whether a particular T-cell receptor repertoire is a useful biomarker or a possible risk factor for the development of platinum salt sensitization requires further investigation. For this purpose it would be interesting to examine the T-cell receptor repertoire in nonsensitized but platinum-exposed workers. 
Acknowledgements. This work was supported by the HVBG (Central Association of the Statutory Accident Insurance Institutions in Industry and Trade), St Augustin, Germany.

\section{References}

1. Karasek SR, Karasek M, eds. The Use of Platinum Paper. Report of the Illinois State Commission of Occupational Diseases to His Excellency. Governor Charles S Deneen, Chicago, Warner Printing Company, 1911; p. 97.

2. Hunter D, Milton R, Perry KMA. Asthma caused by the complex salts of platinum. Br J Ind Med 1945; 2: 92-98.

3. Roberts AE. Platinosis. A five year study of the effects of soluble platinum salts on employees in a platinum laboratory and refinery. Arch Ind Hyg Occup Med 1951; 4: 549-555.

4. Pepys J. Occupational allergy due to platinum complex salts. Clin Immunol Allergy 1984; 4: 131-157.

5. Murdoch RD, Pepys J, Hughes EG. IgE antibody responses to platinum group metals: a large scale refinery survey. Br J Ind Med 1986; 43: 37-43.

6. Merget R, Schultze-Werninghaus G, Muthorst T, Friedrich W, Meier-Sydow J. Asthma due to the complex salts of platinum - a cross-sectional survey of workers in a platinum refinery. Clin Exp Allergy 1988; 18: 569-580.

7. Merget R, Kulzer R, Dierkes-Globisch A, et al. Exposure effect relationship of platinum salt allergy in a catalyst production plant: conclusions from a 5 -year prospective cohort study. J Allergy Clin Immunol 2000; 105: 364370 .

8. Bolm-Audorff U, Bienfait HG, Burkhard J, et al. Prevalence of respiratory allergy in a platinum refinery. Int Arch Occup Environ Health 1992; 64: 257-260.

9. Calverley AE, Rees D, Dowdeswell RJ, Linnett PJ, Kielkowski D. Platinum salt sensitivity in refinery workers: incidence and effects of smoking exposure. Occup Environ Med 1995; 52: 661-666.

10. Biagni RE, Bernstein IL, Gallagher JS, Moorman WJ, Brecks S, Gann PH. The diversity of reaginic immune responses to platinum and palladium metallic salts. $J$ Allergy Clin Immunol 1985; 76: 794-802.

11. Brooks SM, Baker DB, Gann PH, et al. Cold air challenge and platinum skin reactivity in platinum refinery workers. Chest 1990; 97: 1401-1407.

12. Merget R, Schultze-Werninghaus G, Bode F, Bergmann EM, Zachgo W, MeierSydow J. Quantitative skin-prick and bronchial provocation tests with platinum salt. $\mathrm{Br} J$ Ind Med 1991; 48: 830-837.

13. Merget R, Caspari C, Kulzer R, Breitstadt R, Rueckmann A, SchultzeWerninghaus G. The sequence of symptoms, sensitization and bronchial hyperresponsiveness in beginning occupational asthma due to platinum salts. Int Arch Allergy Immunol 1995; 107: 406-407.

14. Pepys J, Parish WE, Cromwell O, Hughes EG. Passive transfer in man and the monkey of type I allergy due to heat labile and heat stable antibody to complex salts of platinum. Clin Allergy 1979; 9: 99-108.
15. Fields BA, Ober B, Malchiodi EL, et al. Crystal structure of the Va domain of a T cell antigen receptor. Science 1995; 270: 1821-1824.

16. Bentley GA, Boulot G, Karjalainen K, Mariuzza RA. Crystal structure of the chain of a $\mathrm{T}$ cell antigen receptor. Science 1995; 267: 1984-1987.

17. De Magistris MT, Alexander J, Coggeshall M, et al. Antigen analog-major histocompatibility complexes act as antagonists of the T cell receptor. Cell 1992; 68: 625634.

18. Martin S, Weltzien HU. T cell recognition of haptens, a molecular view. Int Arch Allergy Immunol 1994; 104: 1016.

19. Vollmer J, Fritz M, Dormoy A, Weltzien HU, Moulon C. Dominance of the BV17 element in nickel-specific human $\mathrm{T}$ cell receptors relates to severity of contact sensitivity. Eur J Immunol 1997; 27: 1865-1874.

20. Griem P, von Vultee C, Panthel K, Best SL, Sadler PJ, Shaw CF. T cell crossreactivity to heavy metals: identical cryptic peptides may be presented from protein exposed to different metals. Eur J Immunol 1998; 28: 1941-1947.

21. Raulf M, Liebers V, Steppert C, Baur X. Increased $\gamma / \delta$ positive T-cells in blood and bronchoalveolar lavage of patients with sarcoidosis and hypersensitivity pneumonitis. Eur Respir J 1994; 7: 140-147.

22. Kappler J, Kotzin B, Herron L, et al. Vß-specific stimulation of human T cells by staphylococcal toxins. Science 1989; 244: 811-813.

23. Forrester JM, Newman LS, Wang Y, King TE Jr, Kotzin BL. Clonal expansion of lung V $\delta 1+\mathrm{T}$ cells in pulmonary sarcoidosis. J Clin Invest 1993; 91: 292-300.

24. Panzara MA, Gussoni E, Steinman L, Oksenberg JR. Analysis of the T-cell repertoire using the PCR and specific oligonucleotide primers. Biol Tech 1992; 12: $728-734$.

25. Raulf-Heimsoth M, Chen Z, Liebers V, Allmers H, Baur $\mathrm{X}$. Lymphocyte proliferation response to extracts from different latex materials and to the purified latex allergen Hev b 1 (rubber elongation factor). J Allergy Clin Immunol 1996; 98: 640-651.

26. Bernstein JA, Munson J, Lummus ZL, Balakrishnan K, Leikauf $\mathrm{G}$. T-cell receptor $\mathrm{V} \beta$ gene segment expression in diisocyanate-induced occupational asthma. $J$ Allergy Clin Immunol 1997; 99: 245-250.

27. Fontenot AP, Kotzin BL, Comment CE, Newman LS. Expansions of T-cell subsets expressing particular T-cell receptor variable regions in chronic beryllium disease. $\mathrm{Am}$ J Respir Cell Mol Biol 1998; 18: 581-589.

28. Beyer K, Häusler T, Kirchner M, Nickel R, Wahn U, Renz $\mathrm{H}$. Specific V $\beta$ T cell subsets are associated with cat and birch pollen allergy in humans. J Immunol 1999; 162: 1186-1191.

29. Loftenius A, Ekstrand J, Möller E. In vitro effects of mercurie chloride $(\mathrm{HgCl} 2)$ on human mononuclear cells. Clin Exp Immunol 1997; 110: 418-422.

30. Loftenius A, Ekstrand J, Möller E. $\mathrm{HgCl}_{2}$-induced human Iymphocyte activation in vitro: a superantigenic mechanism? Int Arch Allergy Immunol 1999; 120: 63-70.

31. Sinigaglia $\mathrm{F}$. The molecular basis of metal recognition by T cells. J Invest Dermatol 1994; 102: 398-401. 